\title{
Determination of pollutant emission of electric vehicle in real traffic conditions in Poland
}

\begin{abstract}
Alternative drives have an increasing share in the global, European and Polish market. The city authorities support primarily the development of electromobility. Progress in these issues is also noticeable in Poland.

The increasing number of battery electric vehicles (BEVs) requires increasing energy costs of the country. Therefore, it is necessary to increase energy production. This work estimates how large this energy surplus should be. For this purpose, it was necessary to determine the average energy consumption of an electric vehicle in real traffic conditions, and then to calculate the average energy demand for a selected number of vehicles. Obtained results were related to pollutant emission considered in the well-to-wheel perspective (including generation of electricity).

In the article, the authors also referred to the minimum number of charging stations for electric vehicles on the Trans-European Transport Network (TEN-T) in Poland. This is a necessary condition on which depends the use of BEV vehicles not only on the territory of cities, but also throughout the country.
\end{abstract}

Key words: electric vehicle, pollutant emission, RDE, environment, electromobility

\section{Introduction}

Electric vehicles are not a novelty in the history of motoring. The first attempts to work on electric vehicles began around 1800 . Their popularity was significant until 1900. In later years they were supplanted by vehicles fueled with conventional fuels [13].

The return to electric vehicles is the result of the increasing emission of harmful exhaust gases and the fight to reduce the impact of transport on greenhouse gas emissions.

According to the IEA report, the number of electric vehicles (EV), hydrogen vehicles (FCEV) and plug-in hybrids (PHEV) on global roads in 2017 reached 3.1 million (an increase of $54 \% \mathrm{y} / \mathrm{y})$. In 2017 , more than 1 million electric cars were sold in total (54\% more than in 2016), half of which (580 thousand) in China. The second place was taken by the United States with a result of 280,000 pieces [3].

On the roads of the Middle Kingdom, currently there are 1.23 million electric vehicles (40\% of the global fleet EV), in Europe 0.82 million, in the US 0.76 million, while in the rest of the world -0.3 million. In 2018, the largest EV share in the new vehicle market was recorded in Norway $(39.2 \%)$, Iceland $(11.7 \%)$ and Sweden $(6.3 \%)$. China $(2.2 \%)$, Germany (1.6\%), USA (1.2\%) and Japan (1.0\%) ranked next. [3]

Electric vehicles are now being identified as one of the main pillars of the future motorization. Until 2030, they are to account for around $30-35 \%$ of all vehicle sales in the world [5].

\section{EV vehicle tests in RDE}

\subsection{Development of the RDE research route}

In order to better determine the real impact of EV vehicles on the environment, it was necessary to determine its real energy consumption in real traffic conditions, according to Real Driving Emissions (RDE) test.

For this purpose, it was necessary to designate a test route that would be representative for the tests and would meet the requirements imposed by the WLTP procedure [14].

Requirements imposed by the legislator are presented in the Table 1.

Determination of the research route (Fig. 1) was dealt with at the Motor Transport Institute. Its development was a priority due to the further possibilities of conducting research [16].

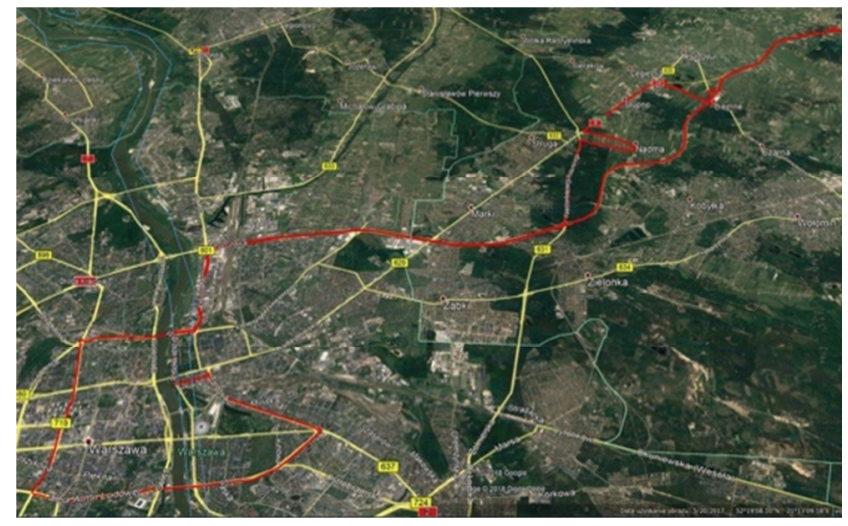

Fig. 1. RDE research route

The designated transit route meets the requirements imposed by the legislator. It complements the WLTP testing procedure. The transit route is representative for Warsaw and allows performing tests in the field of emission tests in accordance with the requirements of the currently applicable WLTP procedure [16].

\subsection{The electric vehicle}

In order to perform EV vehicle tests in real traffic conditions, one of the popular electric vehicles on the European market was used for this purpose. Its selected technical data are presented in the Table 2. In Fig. 2 the research vehicle is presented. 
Table 1. Requirements for the RDE test route [14]

\begin{tabular}{|c|c|}
\hline Parametr & Requirements \\
\hline \multirow{3}{*}{$\begin{array}{l}\text { Outdoor } \\
\text { temperature }\left(\mathrm{T}_{\mathrm{z}}\right)\end{array}$} & normal range: $0^{\circ} \mathrm{C} \leq \mathrm{T}_{\mathrm{z}}<30^{\circ} \mathrm{C}$ \\
\hline & extended bottom range: $-7^{\circ} \mathrm{C} \leq \mathrm{T}_{\mathrm{z}}<0^{\circ} \mathrm{C}$ \\
\hline & extended upper range: $30^{\circ} \mathrm{C}<\mathrm{T}_{\mathrm{z}} \leq 35^{\circ} \mathrm{C}$ \\
\hline \multirow{2}{*}{$\begin{array}{l}\text { The topographical } \\
\text { value of conducting } \\
\text { the research }(\mathrm{h})\end{array}$} & normal range: $\mathrm{h} \leq 700 \mathrm{~m}$ n.p.m. \\
\hline & extended range: $700<\mathrm{h} \leq 1300 \mathrm{~m}$ n.p.m. \\
\hline \multirow{3}{*}{$\begin{array}{l}\text { Assessment of the } \\
\text { impact of external } \\
\text { weather and road } \\
\text { parameters, as well } \\
\text { as driving style }\end{array}$} & $\begin{array}{l}\text { total height increase: less than } \\
1200 \mathrm{~m} / 100 \mathrm{~km}\end{array}$ \\
\hline & $\begin{array}{l}\text { relative positive acceleration (RPA): bigger } \\
\text { than } \mathrm{RPA}_{\min } \text { (for all driving conditions) }\end{array}$ \\
\hline & $\begin{array}{l}\text { Coefficient of velocity and acceleration } \\
\left(\mathrm{v} \cdot \mathrm{a}_{\mathrm{pos}}\right) \text { : less than } \mathrm{v} \cdot \mathrm{a}_{\text {pos min }} \text { (for all test condi- } \\
\text { tions) }\end{array}$ \\
\hline \multirow{2}{*}{$\begin{array}{l}\text { Thermal condition of } \\
\text { the vehicle before } \\
\text { the test }\end{array}$} & $\begin{array}{l}\text { cold start of the vehicle: cooling liquid below } \\
70^{\circ} \mathrm{C} \text {, time at least } 300 \mathrm{~s}\end{array}$ \\
\hline & $\begin{array}{l}\text { no counting of emissions from a cold start to } \\
\text { the RDE test }\end{array}$ \\
\hline $\begin{array}{l}\text { One time vehicle } \\
\text { stop }\end{array}$ & not longer than $180 \mathrm{~s}$ \\
\hline $\begin{array}{l}\text { Operation of exhaust } \\
\text { gas treatment sys- } \\
\text { tems }\end{array}$ & $\begin{array}{l}\text { single regeneration of the diesel particulate } \\
\text { filter may cause the RDE test to be repeated; } \\
\text { the occurrence of two regenerations is includ- } \\
\text { ed in the RDE emission test results }\end{array}$ \\
\hline $\begin{array}{l}\text { Operation of driving } \\
\text { comfort systems }\end{array}$ & $\begin{array}{l}\text { normally used as intended (e.g. operation of } \\
\text { the air conditioning system) }\end{array}$ \\
\hline Vehicle load & $\begin{array}{l}\text { vehicle mass: driver (and passenger) and test } \\
\text { equipment; maximum load }<90 \% \text { of the total } \\
\text { mass of passengers and the payload of the } \\
\text { vehicle }\end{array}$ \\
\hline Test requirements & duration $90-120 \mathrm{~min}$ \\
\hline \multirow{5}{*}{$\begin{array}{l}\text { Requirements for the } \\
\text { urban part of the test }\end{array}$} & share $29-44 \%$ the length of the entire test \\
\hline & distance: greater than $16 \mathrm{~km}$ \\
\hline & vehicle speed $(\mathrm{v}): \mathrm{v} \leq 60 \mathrm{~km} / \mathrm{h}$ \\
\hline & average speed: $15-40 \mathrm{~km} / \mathrm{h}$ \\
\hline & staging: $6-30 \%$ of the time of the urban part \\
\hline \multirow{3}{*}{$\begin{array}{l}\text { Requirements for } \\
\text { the extra-urban part } \\
\text { of the test }\end{array}$} & share of $23-43 \%$ of the total length of the test \\
\hline & distance: greater than $16 \mathrm{~km}$ \\
\hline & vehicle speed $(\mathrm{v}): 60 \mathrm{~km} / \mathrm{h}<\mathrm{v} \leq 90 \mathrm{~km} / \mathrm{h}$ \\
\hline \multirow{5}{*}{$\begin{array}{l}\text { Requirements for } \\
\text { the test section of } \\
\text { the highway }\end{array}$} & share of $23-43 \%$ of the total length of the test \\
\hline & distance: greater than $16 \mathrm{~km}$ \\
\hline & vehicle speed $(\mathrm{v}): \mathrm{v}>90 \mathrm{~km} / \mathrm{h}$ \\
\hline & $\begin{array}{l}\text { driving speed over } 100 \mathrm{~km} / \mathrm{h} \text { for at least } \\
5 \text { minutes }\end{array}$ \\
\hline & $\begin{array}{l}\text { driving speed over } 145 \mathrm{~km} / \mathrm{h} \text { for up to } 3 \% \text { of } \\
\text { the time }\end{array}$ \\
\hline
\end{tabular}

Table 2. Selected technical data of the tested EV vehicle [2]

\begin{tabular}{|l|c|c|}
\hline \multicolumn{1}{|c|}{ Parameter } & Unit & Value \\
\hline Length & $\mathrm{mm}$ & 4140 \\
\hline Width & $\mathrm{mm}$ & 1800 \\
\hline Hight & $\mathrm{mm}$ & 1593 \\
\hline Wheelbase & $\mathrm{mm}$ & 2570 \\
\hline Engine & & $\begin{array}{c}\text { synchronous with permanent } \\
\text { magnets }\end{array}$ \\
\hline Power & $\mathrm{kW}$ & 80.2 \\
\hline $\begin{array}{l}\text { Maximum engine } \\
\text { rotational speed }\end{array}$ & $\mathrm{rpm}$ & 10,500 \\
\hline Range & $\mathrm{km}$ & Around 200 \\
\hline Battery type & $\mathrm{pcs}$ & 192 \\
\hline Number of links & $\mathrm{pcs}$ & 8 \\
\hline Number of modules & $\mathrm{kg}$ & 135 \\
\hline Weight of links & & Lithium-polymer \\
\hline
\end{tabular}

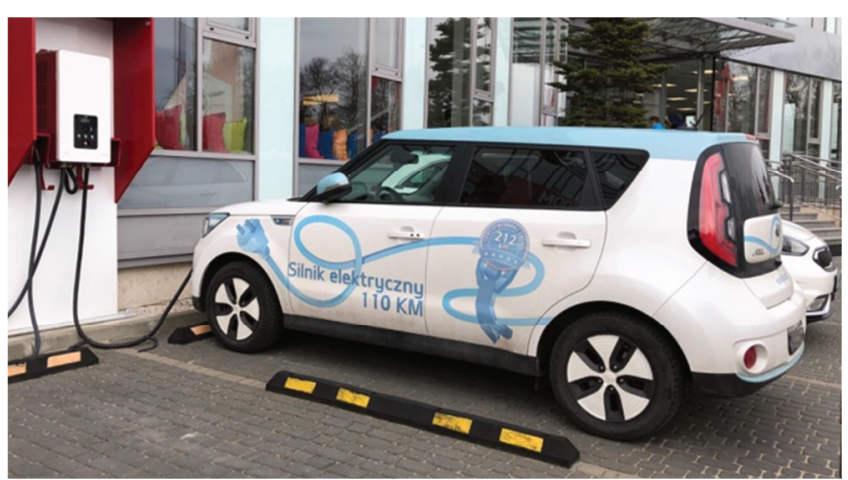

Fig. 2. An electric research vehicle

\subsection{Measuring equipment}

Specialist test equipment was used to test the electric vehicle. The YOKOGAWA WT1806E device (Fig. 3) is a six-channel power analyzer for measuring, among others, power or consumption of energy collected and recovered from batteries and subassemblies of electric and hybrid cars, among others about:

- voltage measurement range $0-1000 \mathrm{~V}$,

- current measurement range: 3 channels $0-5$ A, 3 channels $0-50 \mathrm{~A}$,

- basic accuracy not less than $0.05 \%$ of reading, $+0.05 \%$ of the measuring range,

- measurement update frequency (voltage, current, power) of at least $1 \mathrm{~ms}$,

- sampling rate of $2 \mathrm{MS} / \mathrm{s}, 16-$ bit converter.

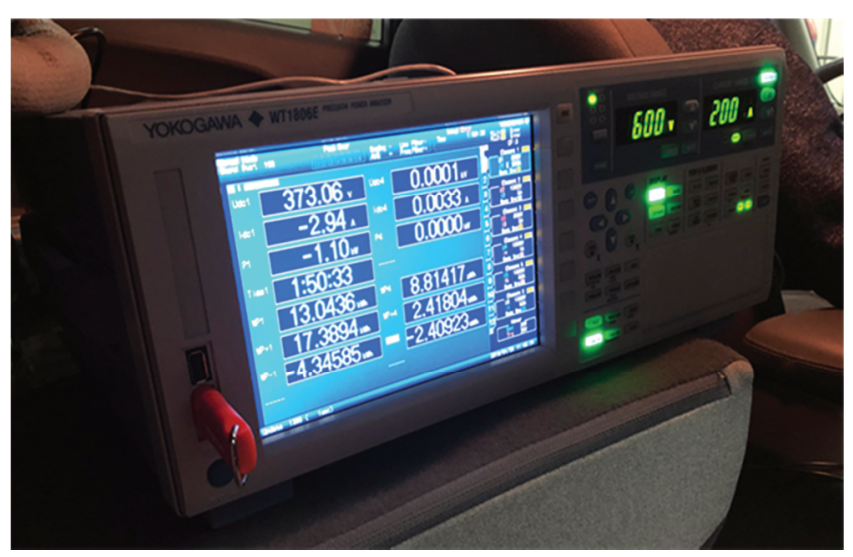

Fig. 3. Research apparatus

\subsection{Test results and analysis}

The tests carried out on the RDE route allowed to determine the average energy consumption of the vehicle. The tests were repeated several times in order to determine the average of the obtained results.

The results from the electric vehicle tests on the RDE route are shown in Table 3.

Table 3. The average energy consumption of the EV vehicle and the average energy taken from the electricity grid during its charging

\begin{tabular}{|l|c|c|}
\hline \multicolumn{1}{|c|}{1} & Unit & Value \\
\hline $\begin{array}{l}\text { Energy consumed } \\
\text { during research in } \\
\text { RDE }\end{array}$ & $\mathrm{kWh}$ & 17.3 \\
\hline $\begin{array}{l}\text { Energy collected } \\
\text { from the mains } \\
\text { while charging }\end{array}$ & $\mathrm{kWh}$ & 14.8 \\
\hline
\end{tabular}


On the basis of own tests of an electric vehicle in real traffic conditions, it was possible to examine its average energy consumption and determine how much electricity is needed to charge the batteries after passing the RDE test. Then it was determined with the assumption of daily runs, what would be the energy demand for one vehicle and energy costs related to it (Table 4).

Table 4. Annual energy consumption needed to recharge the batteries of one vehicle and determine the related costs

\begin{tabular}{|l|c|c|}
\hline \multicolumn{1}{|c|}{ Parameter } & Unit & Value \\
\hline $\begin{array}{l}\text { Daily mileage on business } \\
\text { days }\end{array}$ & $\mathrm{km}$ & 60 \\
\hline $\begin{array}{l}\text { Daily mileage on Sunday and } \\
\text { holidays }\end{array}$ & $\mathrm{km}$ & 60 \\
\hline $\begin{array}{l}\text { Annual mileage on business } \\
\text { days }\end{array}$ & $\mathrm{km}$ & 15,060 \\
\hline $\begin{array}{l}\text { Annual mileage on Sundays } \\
\text { and holidays }\end{array}$ & $\mathrm{km}$ & 6840 \\
\hline $\begin{array}{l}\text { Total mileage } \\
\text { Price 1 kWh for a household } \\
\text { (G11 tariff) }\end{array}$ & $\mathrm{kWh}$ & 21,900 \\
\hline $\begin{array}{l}\text { Annual energy consumption } \\
\text { needed to recharge the } \\
\text { batteries of one vehicle }\end{array}$ & $\mathrm{zł}$ & 3602 \\
\hline $\begin{array}{l}\text { Annual cost of charging one } \\
\text { vehicle }\end{array}$ & & 1981 \\
\hline
\end{tabular}

\section{Impact of EV vehicles on the country's energy demand}

Electricity production will increase by about $40 \%$ from $158 \mathrm{TWh}$ in 2010 to $223 \mathrm{TWh}$ in 2050. It will be connected both with the economic development of Poland and with shifting the demand for final energy from fossil fuels towards electricity, resulting from the growing mechanization of industry and services, the spread of electric vehicles (plug-in hybrids) and electrification of water heating and production processes heat in many households so far using coal or gas for this purpose. This will also entail an increase in the demand for power from the current 29 GW to 42 GW after 2040 [17].

The main producer of electricity throughout the forecast period will be coal-fired power plants. The need to satisfy fast growing demand will necessitate investment in new coal capacities already in the current decade, especially that blocks built in the sixties and seventies of the twentieth century will be phased out. As a result of both processes by 2030 , electricity production in coal-fired power plants will increase by approx. $20 \%$ compared to 2010 . At the same time, the demand for electricity will increase by approx. $40 \%$, and lignite resources in existing mines will start to run out. At the same time, opening new deposits of this raw material will be economically unjustified, as long as the price of carbon dioxide emission allowances will grow in line with the assumptions of the reference scenario. The resulting gap between production and demand for electricity will have to be filled by low-emission technologies [17].

The supplement to the coal-fired power plant in the energy system will be primarily renewable sources supported by gas sources operating primarily in the reserve and working in combination with heat production. The reasons for the increase in the relative importance of RES are two.
First of all, the avalanche development of solar plants in the world causes a rapid drop in solar energy costs for end users [17].

Taking into account a specific plan to introduce in Poland up to 2020 a million electric cars, this value was assumed to be representative in the calculations. Considering the average energy demand for charging an eclectic vehicle determined in own studies and analyzes, it was possible to determine the energy demand for a million vehicles.

Table 5 shows the energy demand of a million electric vehicles.

Table 5. Energy demand for powering electric vehicles

\begin{tabular}{|l|c|c|}
\hline \multicolumn{1}{|c|}{ Parameter } & Unit & Value \\
\hline $\begin{array}{l}\text { Annual energy consumption needed to } \\
\text { recharge the batteries of one electric } \\
\text { vehicle }\end{array}$ & $\mathrm{kWh}$ & 3602 \\
\hline $\begin{array}{l}\text { Annual energy consumption needed to } \\
\text { recharge the batteries of a million electric } \\
\text { vehicles }\end{array}$ & $\mathrm{TWh}$ & 3.602 \\
\hline $\begin{array}{l}\text { An increase in energy demand while } \\
\text { powering a million electric vehicles }\end{array}$ & $\%$ & 2.2 \\
\hline
\end{tabular}

As it results from the above calculations, a million electric vehicles do not have a significant impact on the overall energy demand of the country. In the current situation, when in 2017 the energy demand of the country amounted to $170 \mathrm{TWh}$, the increase in demand for a million electric vehicles would amount to $2.2 \%$.

\section{Well-to-wheel pollutant emission from EV}

It is possible to estimate total emission of air pollutants that can be attributed to EV operation by including the full chain of electricity generation and supply, along with the efficiency of each process considered. Certainly, the result will depend on many factors, i.e. the type of primary energy sources used for electricity generation, technology applied at power station, electricity transmission and distribution losses, efficiency of the vehicle propulsion system, etc. Quantification of pollutant emission for such a wide range is performed in the Well-to-Wheel (WtW) analysis, which takes into account the acquisition of primary energy sources, their processing into energy carriers (electricity or fuel), transport, distribution and final consumption in the vehicle [1]. This approach allows for a comparison of environmental impacts between $\mathrm{EV}$ and conventional vehicles with combustion engine.

WtW analysis is divided into two phases [1]:

- WtT (Well-to-Tank), covering the path of the energy carrier up to the place of its storage in the vehicle,

- TtW (Tank-to-Wheel), covering the energy consumption of the vehicle.

In this study, the $\mathrm{WtW}$ analysis was performed for the EV described in previous chapters. The aim was to determine total annual emission of: carbon dioxide $\left(\mathrm{CO}_{2}\right)$, sulfur dioxide $\left(\mathrm{SO}_{2}\right)$, nitrogen oxides $\left(\mathrm{NO}_{\mathrm{x}}\right)$, carbon monoxide (CO) and particulate matter (TSP) from the EV charged using electricity from power grid in Polish conditions. The scope of the analysis was broken down into the following stages: primary energy sources acquisition and transport, conversion of primary energy sources to electricity at po- 
wer station, electricity trade (import and export of the electricity abroad of Poland), electricity supply post-trade, electricity distribution over the power grid, EV charging at low voltage (typical for most users [15]), and conversion of the electricity to mechanical energy in EV (Fig. 4).

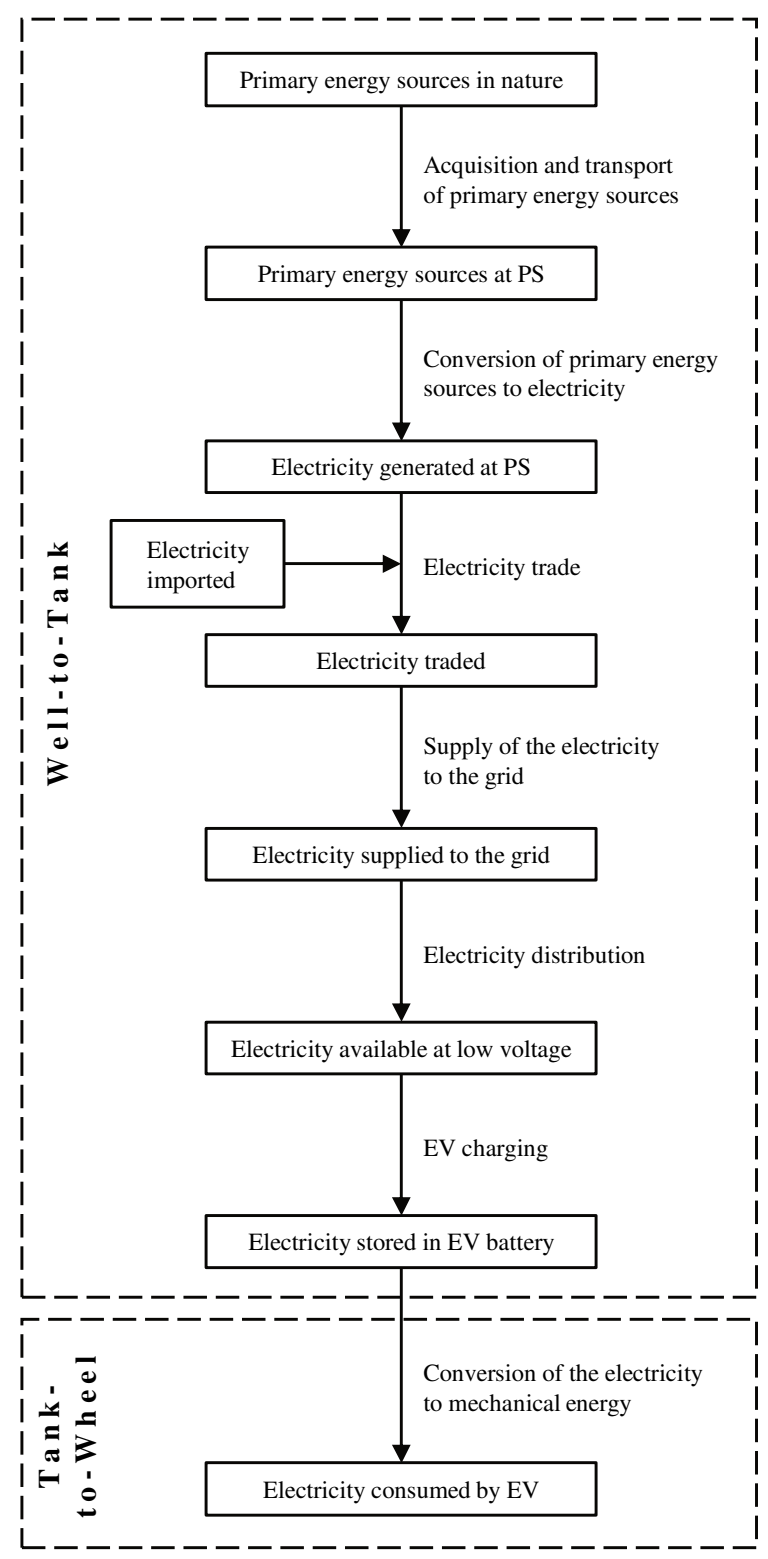

Fig. 4. Stages of the WtW analysis considered in the study; PS - power station

The general research methodology has been adopted from the JEC WTW report version 4a [6, 7]. In the calculations the following assumptions were made:

- EV does not emit air pollutants in the TtW phase,

- renewable primary energy sources do not emit pollutants at the electricity generation stage,

- the data on Polish electricity mix in 2017 (shares of electricity obtained from the combustion of fossil fuels, as well as various renewable energy sources) is derived from the national database on greenhouse gas emissions and other substances, run by KOBiZE (National Centre for Emissions Management) [8],
- emission factors for electricity generation via combustion of fuels are derived from KOBiZE report for 2017 [9],

- emission factors concerning acquisition and transport of primary energy sources to power station are adopted from [11],

- data on electricity traded with other countries was taken from [11].

Table 6 presents the results of calculations of equivalent emission of pollutants for $1 \mathrm{kWh}$ of electricity needed for charging $\mathrm{EV}$ at low voltage.

Table 6. Calculated emission factors for electricity needed for charging $\mathrm{EV}$ at low voltage in Polish conditions

\begin{tabular}{|c|c|c|c|c|c|}
\hline $\begin{array}{c}\text { Pollutant } \\
\text { (equivalent) }\end{array}$ & $\mathrm{CO}_{2}$ & $\mathrm{SO}_{2}$ & $\mathrm{NOx}$ & $\mathrm{CO}$ & $\mathrm{TSP}$ \\
\hline Unit & $\mathrm{g} / \mathrm{kWh}$ & $\mathrm{mg} / \mathrm{kWh}$ & $\mathrm{mg} / \mathrm{kWh}$ & $\mathrm{mg} / \mathrm{kWh}$ & $\mathrm{mg} / \mathrm{kWh}$ \\
\hline Value & 881 & 825 & 837 & 300 & 50 \\
\hline
\end{tabular}

Taking into account the annual energy demand for one $\mathrm{EV}$ in Poland (3602 $\mathrm{kWh}$ ), annual pollutant emission that can be associated with charging the batteries of EV was calculated. It is presented in Fig. 5.

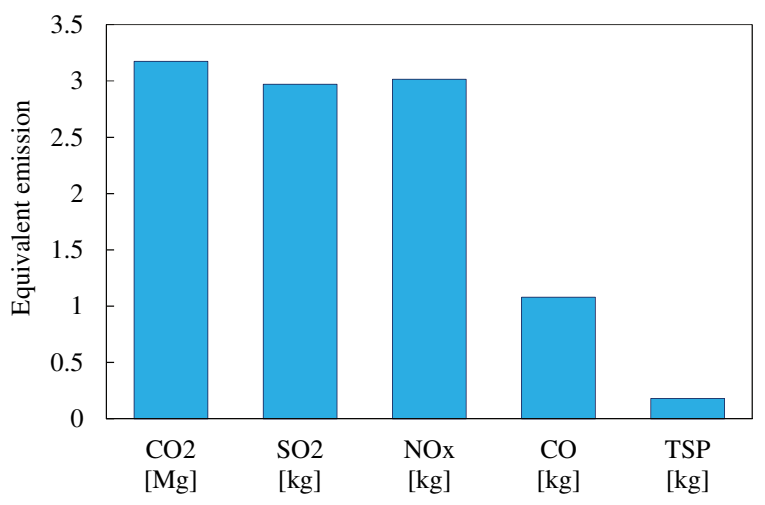

Fig. 5. Annual emission of pollutants associated with charging the batteries of one EV in Polish conditions

Consequently, the total potential emission of pollutants as a result of charging the batteries of one million EVs in Poland can be calculated. The results are given in Table 7.

Table 7. Total potential emission of pollutants associated with charging the batteries of one million EVs in Poland

\begin{tabular}{|c|c|c|c|c|c|}
\hline $\begin{array}{c}\text { Pollutant } \\
\text { (equivalent) }\end{array}$ & $\mathrm{CO}_{2}$ & $\mathrm{SO}_{2}$ & $\mathrm{NO}_{\mathrm{x}}$ & $\mathrm{CO}$ & $\mathrm{TSP}$ \\
\hline Unit & $\mathrm{kg}$ & $\mathrm{kg}$ & $\mathrm{kg}$ & $\mathrm{kg}$ & $\mathrm{kg}$ \\
\hline Value & $3.17 \cdot 10^{9}$ & $2.97 \cdot 10^{6}$ & $3.01 \cdot 10^{6}$ & $1.08 \cdot 10^{6}$ & $0.18 \cdot 10^{6}$ \\
\hline
\end{tabular}

\section{Comparison of well-to-wheel pollutant emission from $\mathrm{EV}$ and conventional vehicle}

In order to better understand and evaluate the results of WtW analysis made for EV (chapter 4), they were compared with the results of $\mathrm{WtW}$ analysis for conventional vehicle with an internal combustion engine (ICEV). The ICEV chosen for comparison had similar technical parameters (Table 8) to the EV and was equipped with a compression-ignition engine supplied with diesel oil. 
Table 8. Selected technical data of the tested ICEV [2]

\begin{tabular}{|l|c|c|}
\hline \multicolumn{1}{|c|}{ Parameter } & Unit & Value \\
\hline Length & $\mathrm{mm}$ & 4278 \\
\hline Width & $\mathrm{mm}$ & 1777 \\
\hline Hight & $\mathrm{mm}$ & 1658 \\
\hline Wheelbase & $\mathrm{mm}$ & 2555 \\
\hline Engine type & & $\begin{array}{c}\text { Compression-ignition, } \\
\text { 4-cylinder, Common rail }\end{array}$ \\
\hline Engine displacement & $\mathrm{cm}^{3}$ & 1686 \\
\hline Maximum power & $\mathrm{kW} \mathrm{@} \mathrm{rpm}$ & 96@4000 \\
\hline Maximum torque & $\mathrm{Nm} \mathrm{@} \mathrm{rpm}$ & 300@2000-2500 \\
\hline Gearbox type & & Manual \\
\hline
\end{tabular}

Fuel consumption and pollutant emission concerning the operation of ICEV, i.e. in the TtW phase, were determined in real traffic conditions using exactly the same RDE test route as for the EV (chapter 2). The concentration of exhaust compounds $\left(\mathrm{CO}_{2}, \mathrm{CO}, \mathrm{NO}_{\mathrm{x}}\right)$ and the exhaust gas flow rate were measured using portable exhaust gas analyzer SEMTECH DS from Sensors Inc. The results of road tests are presented in Table 9. Note that the emission of $\mathrm{SO}_{2}$ and $\mathrm{PM}$ was not included in the tests. Instead, $\mathrm{SO}_{2}$ emission in TtW phase was determined from fuel consumption using emission factor according to the Ecoinvent database [4]. On the other hand, PM emission was excluded from the comparative analysis due to the lack of adequate empirical test results, while its theoretical estimation would be subject to significant uncertainty, taking into account the high impact of engine operating conditions on the emission of this pollutant.

Table 9. Fuel consumption and pollutant emission of ICEV in the TtW phase - results of RDE test

\begin{tabular}{|c|c|c|c|c|c|}
\hline & $\begin{array}{c}\text { Fuel con- } \\
\text { sumption }\end{array}$ & $\begin{array}{c}\mathrm{CO}_{2} \\
\text { emission }\end{array}$ & $\begin{array}{c}\mathrm{SO}_{2} \\
\text { emission }\end{array}$ & $\begin{array}{c}\mathrm{NO}_{\mathrm{x}} \\
\text { emission }\end{array}$ & $\begin{array}{c}\mathrm{CO} \\
\text { emission }\end{array}$ \\
\hline Unit & $\mathrm{dm}^{3} / 100 \mathrm{~km}$ & $\mathrm{~g} / \mathrm{km}$ & $\mathrm{mg} / \mathrm{kg}$ & $\mathrm{mg} / \mathrm{km}$ & $\mathrm{mg} / \mathrm{km}$ \\
\hline Value & 5.9 & 157.50 & 5.02 & 201.17 & 148.10 \\
\hline
\end{tabular}

The data from Ecoinvent [4] were also used to calculate the emission of pollutants related to the production, transport and distribution of diesel oil, i.e. in the WtT phase (Table 10). To avoid the impact of additional assumptions on the results of the analysis in the $\mathrm{WtT}$ phase, the standard approach from Ecoinvent was adopted. It is adequate to European conditions.

Table 10. Pollutant emission associated with the production, transport and distribution of diesel oil in European conditions - the WtT phase

\begin{tabular}{|c|c|c|c|c|}
\hline Pollutant & $\mathrm{CO}_{2}$ & $\mathrm{SO}_{2}$ & $\mathrm{NO}_{\mathrm{x}}$ & $\mathrm{CO}$ \\
\hline Unit & $\mathrm{g} / \mathrm{kg}$ & $\mathrm{g} / \mathrm{kg}$ & $\mathrm{g} / \mathrm{kg}$ & $\mathrm{g} / \mathrm{kg}$ \\
\hline Value & 491.89 & 4.390 & 1.797 & 0.148 \\
\hline
\end{tabular}

Finally, a total emission of pollutants was obtained, combining the TtW and WtT phases. The results for ICEV were compared with the results for EV (Fig. 6).

Analyzing the results of WtW shown in Fig. 6, it is clear that EV has lower overall environmental load than ICEV when considering both the use of the vehicle and the production of fuel or electricity. It is worth emphasizing that this result was obtained for Polish conditions, where the majority of electricity is generated by burning hard and brown coal. In countries with a higher share of renewable energy in the electricity mix, e.g. Norway, the difference between WtW pollutant emission for EV and ICEV would be even greater.

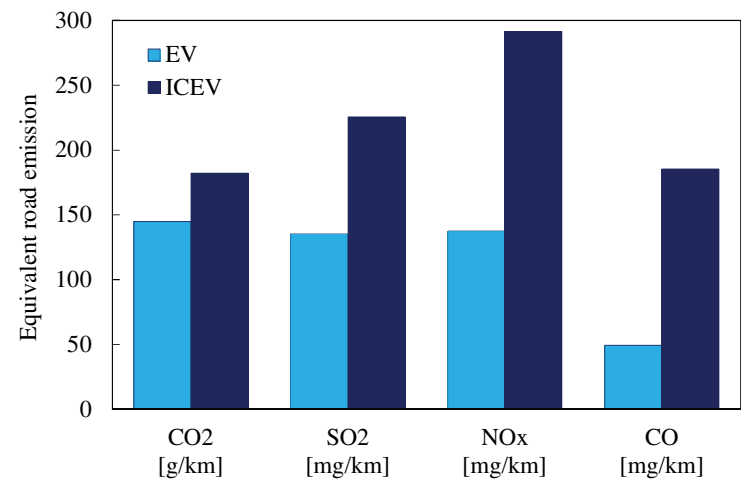

Fig. 6. Comparison of WtW emission for EV and ICEV

\section{Number of EV vehicle charging stations on the TEN-T road network and its impact on the environment}

The Trans-European Transport Network (TEN-T) is an instrument for the coordination and ensuring coherence and complementarity of infrastructure investments [10].

As a result of the revision of the TEN-T guidelines completed in 2013, a new agreement has been established on the territory of the EU Member States. This system includes a core network that underpins the development of the transport network on which EU activities are to focus, in particular on cross-border sections, missing links, multimodal connections and major bottlenecks, and a comprehensive network ensuring the availability and connectivity of all Union regions [10].

The trans-European TEN-T transport network includes [10]:

- road, rail, air, sea and river routes constituting the most important connections from the point of view of the development of the European Union,

- point elements of infrastructure in the form of sea, air, inland and road-rail terminals.

Taking into account such variables as the location and infrastructure of given road sections, the number of fast charging points for electric vehicles was determined. Their minimum amount is 60 points. With such infrastructure, it will be possible to use electric vehicles on roads belonging to transport routes

TEN-T and constituting road sections that will be heavily loaded in the perspective of 2020, without worrying about the lack of space for charging vehicles. Assuming that 3.602 TWh of energy and the efficiency of chargers placed next to the TEN-T network is $95 \%$ needed to supply one million vehicles [12], annual real energy demand will amount to $3.752 \mathrm{TWh}$.

\section{Conclusions}

Electric cars are considered the future of motoring. They are becoming more and more popular. In addition, there are a number of benefits related to the operation or subsidies for their purchase. 
EV vehicles in daily use require the vehicle to be charged. As a result, the energy demand of the country increases. As it results from the calculations presented in the article, the increase in the demand for electricity for a million EV vehicles, only amounts to $2.2 \%$. On the scale of national energy demand, this is not much.

The article also presents the total potential emission of pollutants associated with charging batteries of one million electric vehicles in Poland - WtW (Well-to-Wheel). Calculations show that the emission equivalent is: for $\mathrm{CO}_{2}-$ $3.17 \cdot 10^{9} \mathrm{~kg}, \mathrm{SO}_{2}-2.97 \cdot 10^{6} \mathrm{~kg}, \mathrm{NO}_{\mathrm{x}}-3.01 \cdot 10^{6} \mathrm{~kg}, \mathrm{CO}-$ $1.08 \cdot 10^{6} \mathrm{~kg}, \mathrm{TSP}-0.18 \cdot 10^{6} \mathrm{~kg}$. WtW pollutant emission for electric vehicle was compared with $\mathrm{WtW}$ emission for conventional vehicle, equipped with compression-ignition engine. It was found that electric vehicle has lower overall emission of pollutants than conventional vehicle when considering vehicle operation and the production of fuel or electricity.

After calculations of the emission related to the charging of an electric vehicle, the article focuses on determining the minimum number of EV vehicle charging stations on the TEN-T road network. It turns out that 60 charging points located on the main transit routes in Poland are sufficient to efficiently use EV vehicles.

\section{Nomenclature}

$\mathrm{CO}$ carbon monoxide

$\mathrm{CO}_{2} \quad$ carbon dioxide

$\mathrm{EV} \quad$ electric vehicle

KOBiZE Krajowy Ośrodek Bilansowania i Zarządzania Emisjami

$\mathrm{NO}_{\mathrm{x}} \quad$ nitrogen oxides

$\mathrm{RDE} \quad$ real driving emissions
$\mathrm{SO}_{2} \quad$ sulfur dioxide

TEN-T Trans-European Transport Network

TSP Total Suspended Particles

WLTP Worldwide harmonised Light duty vehicle Test Procedure

\section{Bibliography}

[1] CHŁOPEK, Z., LASOCKI, J. Comprehensive evaluation of the environmental hazard caused by the operation of automotive vehicles. The Archives of Automotive Engineering Archiwum Motoryzacji. 2011, 54(4), 19-36.

[2] http://kia.com

[3] http://www.elektro.info.pl/aktualnosc/id8599, iea-liczbapojazdow-elektrycznych-na-swiecie-przekroczyla-3-mln-sztuk

[4] https://www.ecoinvent.org/

[5] https://wysokienapiecie.pl/13819-stacje-ladowaniapowstaja-przy-trasach-i-w-miastach/

[6] JEC (JRC-Eucar-Concawe). Tank-To-Wheels Report Version 4a - Well-to Wheels Analysis of Future Automotive Fuels and Powertrains in the European Context. Available at: https://ec.europa.eu/jrc/en/jec

[7] JEC (JRC-Eucar-Concawe). Well-To-Wheels Report Version 4.a: Well-to Wheels Analysis of Future Automotive Fuels and Powertrains in the European Context. 2014. Available at: https://ec.europa.eu/jrc/en/jec

[8] KOBiZE. The national database on greenhouse gas emissions and other substances. Available at: krajowabaza.kobize.pl/

[9] KOBiZE. Wskaźniki emisyjności $\mathrm{CO}_{2}, \mathrm{SO}_{2}, \mathrm{NO}_{\mathrm{x}}, \mathrm{CO}$ i pyłu całkowitego dla energii elektrycznej na podstawie informacji zawartych w Krajowej bazie o emisjach gazów cieplarnianych i innych substancji za 2017 rok, 2018.

[10] mib.gov.pl.

\footnotetext{
Maciej Gis, DEng. - Environment Protection Centre in Motor Transport Institute. e-mail:maciej.gis@its.waw.pl
}

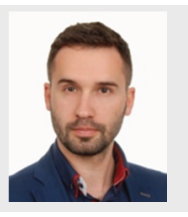

Jakub Lasocki, DEng. - Faculty of Automotive and Construction Machinery Engineering, Warsaw University of Technology.

e-mail: jakub.lasocki@pw.edu.pl
[11] MORO, A., LONZA, L. Electricity carbon intensity in European Member States: Impacts on GHG emissions of electric vehicles. Transportation Research Part D: Transport and Environment. 2018, 64, 5-14. DOI: 10.1016/ j.trd.2017.07.012

[12] CZYŻ, P., CICHOWSKI, A. Przegląd systemów ładowania elektrycznych osobowych pojazdów i koncepcja dwukierunkowej ładowarki pokładowej. Zeszyty Naukowe Wydziału Elektrotechniki i Automatyki Politechniki Gdańskiej. 2017, 57.

[13] RAJASHEKARA K. Present status and future trends in electric vehicle propulsion technologies. IEEE Power\&Energy Society. 2013.

[14] Rozporządzenie Wykonawcze Komisji (UE) 2018/1002 z dnia 16 lipca 2018 r. zmieniające rozporządzenie wykonawcze (UE) 2017/1153 w celu wyjaśnienia i uproszczenia procedury korelacji oraz dostosowania jej do zmian w rozporządzeniu (UE) 2017/1151.

[15] UN ECE. Regulation 101, Rev.3. United Nation Economic Commission for Europe. 2013. Available at: http://www. unece.org/ trans/main/wp29/wp29regs101-120.html.

[16] Wdrożenie procedury dotyczącej przejazdu dla realizacji badań emisji zanieczyszczeń spalin (RDE). Praca statutowa 06/18/ITS/008. Instytut Transportu Samochodowego.

[17] Wnioski $\mathrm{z}$ analiz prognostycznych na potrzeby Polityki energetycznej Polski do 2050 roku. Załącznik 2 do Polityki energetycznej Polski do 2050 roku. Ministerstwo Gospodarki. Warszawa 2015.

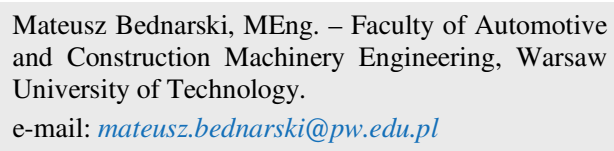

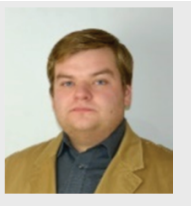

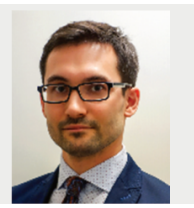

